\title{
META-SUBJECT RESEARCH IN POLISH PEDAGOGY. INTRODUCTION TO THE SUBJECT MATTER
}

\begin{abstract}
The article is introductory, elementary. Its purpose is problem analysis of selected aspects of the achievements of pedagogy in the field of meta-subject research. It addresses issues related to the genesis of meta-subject research, its definition, typologization, function and criticism.
\end{abstract}

Keywords: meta-subject research; pedagogy; genesis of meta-subject research; types of meta-subject research; functions of meta-subject research.

\section{Introduction}

The subject of the article is the achievements of Polish pedagogy in the field of meta-subject research. The purpose of the analysis is to determine the specifics of the metapedagogical approach in the field of genesis, how to build theoretical explorations and undertaken research problems. The author answers the following questions: (1) what is the genesis of meta-subject research in Polish pedagogy? (2) how have the studies developed so far? (3) how are the studies defined and typologized? (4) what functions are assigned to them? and (5) what specific methodological problems arise in research conducted at the meta level?

The present article is problem-oriented. It means that its content presents methodological aspects of the issue. However, some historical data illustrating the environmental background of this issue has also been included.

The author's research process can be described as analytical. The professional literature was the source for his interpretation of the concepts and theses. However, only Polish research data has been taken into consideration.

The study presented here does not aspire to exhaust the topic or to provide a systemic explanation of the specifics of Polish meta-subject research in pedagogy.

* PhD habil. Piotr Magier, the John Paul II Catholic University of Lublin, Poland, Faculty of Social Sciences; e-mail: piotr.magier@kul.lublin.pl. 
According to the title, the intention of the author is to prepare the foundation for further analysis that seems worth continuing. Conceptsdiscussed in this article havebeen presented in more detail in a separate publication (Magier, 2019).

Since this article is published in English, I hope that it will provide an inspiration for both foreign and Polish scientists interested not only in Polish pedagogy, but also in meta-subject research. This text may pose some challenges because it does not refer directly to education, but to less known, underlying issues. Despite the fact that the subject matter of meta-subjects belongs to the core of contemporary pedagogical knowledge, determining its nature causes considerable problems, and metapedagogical research remains unidentified.

\section{The origin of meta-subject research}

Contemporary meta-subject research conducted in the area of Polish pedagogy is based on two sources. The first is philosophy, and the other is the methodology of pedagogical research. It seems that the methodological reflection conducted in the field of philosophy precedes its pedagogical counterpart and is a source for metapedagogical considerations. Undoubtedly, its level is also more advanced. The genesis of pedagogical meta-subject research is associated with the process of crystallizing its autonomy as a separate humanistic discipline.

\section{Meta-subject research in philosophy}

The beginnings of meta-subject research can be traced back to the dawn of philosophy. During the period of Ancient Greece it was conducted along with subject research. The meta-subject research was not defined by a separate name and was of elementary nature. It studied charateristics of philosophy: distinguishing philosophical knowledge from other types of knowledge (poetry, religion, tradition), determining the essence of human cognition and philosophy-specific research methods with its structure (Rembierz, 2011).

In the Middle Ages, meta-subject research appeared in the form of epistemological and methodological reflections. Their special case was the axial problem for scholasticism of the relation between rational knowledge (philosophy) and revealed knowledge (Judeo-Christian revelation) (Zięba, 2014).

The dynamic development of meta-subject research can be observed at the turn of the 19th and 2oth centuries. During this time many disciplines chose science as their subject of research. Meta-geometry, meta-mathematics, meta-ethics and metalogic were developed, among others. In the 1940s, Morris Lazerowitz promoted the term 'metaphilosophy', while Kazimierz Ajdukiewicz introduced the term 'metascience' (metanauka) into scientific terminology, which was later popularized by Gerard Radnitzky in the 1970s as the English term metascience (Woleński, 2011; Jusiak, 2006). 
The naturalistic model of doing science remains an important determinant of the discussion on the meta-subject perspective. This discussion was initiated by a positivist critique of any type of science other than natural science (e.g. theological, philosophical, humanistic), which resulted in the reflection and defense of the scientific status of non-empirical sciences. Wilhelm Dilthey is considered the initiator of this defense (Kamiński, 1992). It was also important for the development of pedagogical methodology.

The environment of Polish philosophers actively participated in promoting metasubject research. Already in early 2oth century it was the subject of the interest for representatives of the so-called Lviv-Warsaw School of (Analitical) Philosophy. The product of their work is the development of meta-subject and science research after the Second World War. Such research was carried out at universities in Warsaw, Wroclaw, Poznan and Lublin (Bronk \& Majdański, 2010).

The meta-subject research conducted by representatives and persons associated with the Lviv-Warsaw School was not limited to philosophical and methodological issues. They also undertook psychological analyses of scientific and, more specifically, philosophical knowledge. After World War I, Józef Pieter studied the psychological foundations of philosophy, developing the humanistic type of metasubject research (Rembierz, 2011).

In simple terms, it can be said that in Polish pedagogy two models of conducting meta-subject research related to philosophical problems have emerged. One of models wasbased on systemic analyses that were conducted at the interface of pedagogy and philosophy (especially Neo-thomism) as well as pedagogy and ideology (Marxism). The other model is science and methodological research (Śliwerski, 2007).

Neo-thomists took a systemic approach to studying pedagogy. This approach was characterized by maximalism, or the universalization of the position presented and the critical attitude towards other theoretical proposals. Pedagogy is included in them as a science with close historical and content connections with philosophy. It is understood either as part of philosophy (Jacek Woroniecki) or as a science based on the achievements of philosophy (Mieczysław A. Krąpiec, Mieczysław Gogacz, Andrzej Maryniarczyk, Henryk Kiereś, Barbara Kiereś). Pedagogy understood as applied philosophy (ethics) is to protect itself against the loss of uniqueness that results from the naturalistic critique of normativeness and postulation of science. Currently the autonomy of pedagogy based on its empirical nature is allowed, subject to the verification of the human development and education models existing within pedagogy in relation to the criteria of realistic anthropology (adequate anthropology, category of anthropological error) (Horowski, 2015; Magier, 2010).

The relationship between Marxism and pedagogy (particularly intense during the Polish People's Republic) resulted in the creation of Marxist pedagogy, represented by Heliodor Muszyński and Miron Krawczyk. This pedagogy was practiced in accordance with the positivist paradigm. The starting point was an empirical 
study of educational phenomena and processes. They were generalized as part of a critically practiced theory of education, in which Marxist ideology was the source of normativity (Śliwerski, 2007; Hejnicka-Bezwińska, 2008).

Nowadays, apart from the metapedagogical research related to philosophy, similar research is also being developed in cooperation with other humanities. The subject of the analyses indicates the relationships between research issues, language, research methods, theoretical assumptions of pedagogy and auxiliary or basic sciences. It is specifically concerned with psychology and sociology whose relationship with pedagogy is systemic (Nowak, 2008).

Pedagogical analyses, which arise in the context of science and methodology of cognition, have a different character. They are performed by such scientists as Andrzej Bronk, Stefan Sarnowski, Agnieszka Salamucha and Monika Walczak. Unlike the theoretical, maximalistic and postulative nature of the Neo-thomists' metapedagogical theses, these analyses described and explained methodologically with external and internal elements (criteria of autonomy) of pedagogy.

External elements refer to the social, cultural and administrative aspect of the functioning of pedagogy. They do not describe its methodological essence (nature), but only define aspects that answer the question whether a particular type of knowledge is considered to be scientific within a given social and legal system. They include specific issues, such as names, scientists, administrative units, achievements, history, and social demand for a specific type of research (Bronk, 2003).

Internal elements relate to the aspect of essence. They determine the nature of a particular science, but their description is not clear-cut, it is the subject of discussion and controversy. They include the subject of research, issues, structure, language, research methods, objectives, output data and initial assumptions. Comments formulated in these areas form the basis for determining its cognitively valuable aspects as well as methodological weaknesses (Bronk, 2003). In this approach, the relationship of pedagogy with other sciences or theories is also the subject of analysis.

\section{Meta-subject research in pedagogy}

Despite the fact that meta-subject research seems to be specific to philosophy, its genetic presence is also clearly marked in pedagogy. The beginnings of Polish metapedagogical analysis can be traced long before the constitution of pedagogy as an independent scientific discipline. The reflection of this type is already clearly present in the works of Jan Amos Comenius, as well as the activities of such institutions as the Commission of National Education.

Apart from educational content, J. A. Comenius' works also included science projects used to generate science conducive to teaching omnes, omnia et omnino (everyone about everything and in depth). Comenius characterized the basic aspects of the scientific functioning of pedagogy. He included goals, methods and language 
(definitions) of pedagogy. In addition, he studied theoretical grounding, and more precisely the pedagogy-based opportunity and necessity of education (Kot, 1996).

The decisions adopted by the Commission of National Education took a different, though equally innovative approach. They did not care about the theoretical aspect but referred to the practical functioning of teacher studies. They defined some elements of their administrative autonomy. It was primarily about introducing the requirement of university teacher pedagogy studies, and thus isolating teachers as a separate identity (Kot, 1996).

However, Johann F. Herbart's lifework is crucial to meta-subject reflection in pedagogy ${ }^{1}$. In the administrative, socio-cultural and methodological aspects, this author contributed to the rise of pedagogy as a university discipline. Herbart earned the first postdoctoral degree in pedagogy, which he defended at the University of Göttingen in 1806. In addition, he created the first institution of teacher education, where pedagogy was studied and practiced. He conducted a seminary of pedagogy at the University of Königsberg. He also published the first pedagogy textbook The science of education, its general principles deduced from its aim, in which he presented the original model of the structure of pedagogy as practical knowledge (Nowak, 1999; Stępkowski, 2008).

The dynamic development of meta-subject research in pedagogy took place after 1918 when Poland regained independence and the higher education system was being revived. Meta-subject issues were included in the curriculum of pedagogical studies preparing future teachers. Proposals for meta-subjective concepts included the general pedagogy of such theorists as Antoni Danysz, Sergiusz Hessen, Zygmunt Kukulski, Zygmunt Mysłakowski, Andrzej Niesiołowski, Stefan Kunowski, Henryk Rowid, Kazimierz Sośnicki (Nowak, 1999; Kostkiewicz, 2017).

After the Second World War, meta-subject issues were also present in Polish pedagogy. Despite the fact that socialist authorities were reluctant to think philosophically and hampered the practice of philosophical pedagogy, including general pedagogy, some authors of this period conducted research on contemporary pedagogical trends and directions, as well as pedagogical methodology.

The renaissance of the above-mentioned meta-subject studies took place after 1989, when the positivist-Marxist paradigm of practicing pedagogy was replaced by the poly- or multi-paradigmatic approach. It generated typical for those times, meta-subjective problems, typical of those times. They included the identity of pedagogy, its dependence on ideology and worldview, the relationship of theory to practice, methodological status (Kwieciński, 1993; Nowak, 1996, Śliwerski, 2007).

Nowadays, meta-subject research in the field of pedagogy is becoming more and more popular. What is interesting is the fact that it is not anonymous research

1 Although it is difficult to call Herbart a Polish educator, the impact he had on Polish pedagogy (as well as the University of Königsberg where he worked) allows him to be included in the text on Polish meta-subject research (Milerski, 2005). 
with no specific label, e.g. "metapedagogy", but a clearly defined and identifiable assignment within this range of scientific interests. "Metapedagogy", "metatheory of education", "discourse of metatheoretic in pedagogy" are the labels that frequent pedagogical literature. These studies concern the methodological status of pedagogy, its theoretical foundations, comparative analyses of contemporary trends and the concept of education (Śliwerski, 2019).

\section{Defining and typologizing meta-subject research}

Meta-subject studies are defined differently. The proposal of the masters of meta-subject research in the philosophy of M. Lazerowitz and K. Ajdukiewicz, the masters of meta-subject research in philosophy, proposed that the object ofthis research be science (en bloc) or selected particular sciences. The name meta-science means science of the science. Therefore, meta-subject research does not concern specific phenomena, processes, facts or natural and cultural conditions, but refers to science itself (Gutowski \& Szubka, 1997; Woleński, 2011).

The problem, however, is how to define scientific research. It can be conducted as philosophical (formal) or humanistic research, i.e. relating to the history of science or its substantive aspects, such as mental, social, cultural, economic and finally educational (Kamiński, 1992).

What is more, meta-subject research can be conducted as part of separate, autonomous sciences (e.g. philosophy of science, theory of science, methodology of science, psychology of science, sociology of science, etc.) or constitute an aspect (part) of research conducted in the subject (particular) sciences. Answers to questions about the methodological characteristics of a certain science can be provided not only from the perspective of separate meta-sciences, but also by the scientists who reflect on the scientific activity they conduct. The importance of both approaches is unique. The first of them sets standards for this type of research and indicates the general regularities to which science is subjected. Research from the perspective of particular sciences, on the other hand, provides a more detailed content and standards developed at the general level. Their cognitive value relates to the research uniqueness of individual subject sciences (Jakiel, 2015).

Differences in conducting meta-subject research also result from typology. The studies can be conducted as methodological studies or as meta-theoretical studies. The first approach is about the characteristics of the subject of research, research issues, language, research methods and structure, results, name. In the other approach, meta-subject research refers to the theoretical foundations of pedagogy. It includes a description and explanation of metaphysical, epistemological, anthropological, ethical, social, psychological and biological foundations of pedagogical theories (Kostkiewicz, 2017).

Difficulties in defining meta-subject research are also generated by inconsistent terminologies. In addition to the term "meta-subject research" or "meta-subject 
science" used so far in this text, such names as "meta-theoretical research", "metascience", "science" and "methodology" are also used. It is by no means easy to define their concepts and, as a consequence, the scoperelationships between them. Even the experts in meta-subject research do not agree on the functioning solutions, ultimately leaving the issue of the convention adopted in a given environment or limiting the existence of various approaches (Ajdukiewicz, 2006; Bronk \& Majdański, 2010; Magier, 2019).

\section{Functions of meta-subject research}

Defining and typologizing meta-subject research is equally challenging as identification of its function of meta-subject research. It is not difficult to indicate the importance and functions of subject sciences, especially the specific ones, which, thanks to the fact that they are often applied sciences are used to transform reality and improve the conditions of human life. Things are much worse with meta-subject sciences. We will struggle to indicate their direct impact on nature, culture and society. The results of research conducted in these areas do not (at least directly) transform the environment, but they are invaluable for understanding and performing science (Materne, 2001).

Meta-subjective sciences, like other sciences, perform cognitive and practical functions. They describe and explain science and also serve to assess the correctness of research procedures. They also postulate proper ways of conducting research and structuring scientific knowledge. Cognitive functions are, of course, basic for any science. However, in the case of meta-subject sciences, it is difficult to directly notice their practical functions. However, this is not a major problem in subject sciences.

The practical functions of sciences cultivated at the meta level can be reduced to the critical, verifying, ordering, identity and course of study. The critical and verifying functions refer to the reliability of scientific statements, the correctness of how they are justified and the accuracy of scientific research procedures (Bronk, 2003). The implementation of these functions stems from methodical skepticism that suggests caution towards the credibility of scientific knowledge. The variety of concepts functioning in science, especially in the humanities, makes us take them with a pinch of salt and reconsider their validity (truthfulness). It is not about skepticism or even agnosticism, identified with the negation of any scientific knowledge. Methodical skepticism is in the opposition to these attitudes and a naive belief in the validity of theses, only because they are collocated with the term "scientific" (Danysz, 1918).

The critical and verifying function of meta-subject research is particularly important in relation to the humanities. The point is that humanistic knowledge contains a number of premises that are not subject to empirical assessment (neither verification nor falsification). These are postulates, normative statements, and those that are advanced deductively. Their coherence can raise doubts, and the functions 
they perform are not clear (the cognitive and practical functions of scientific statements and categories are mixed). As a result, the humanities are sometimes seen as the biggest threat to the rationality of science (Bronk, 2003).

The value of the ordering and identity functions of meta-subject research is particularly evident in relation to similar sciences. Especially in the humanities, sciences are hard to tell apart. This dilemma is clearly about pedagogy that has a lot in common with psychology or sociology.

Its reference to the aspect of scientific language is a specific case of implementing the ordering function of science. The terminological mess that prevails in the humanities seems impossible to control. Humanists often do not respect the postulate of terminological precision. They coin their own neologisms that do not respect the terminological traditions of specific science or introduce new terminologies, oftentimes borrowings from foreign languages (mostly English) (Bronk, 2003).

As a result, knowledge of the principles and nature of science (or a particular scientific discipline) is the basis for propaedeutical activities. Although detailed problems are not explained in their scope, they provide the basis for understanding what a particular science is and how to do it properly, which seems valuable for upcoming scientists (Bronk \& Majadański, 2010).

\section{Detailed problems with the implementation of meta-subject research}

Conducting meta-subject research is accompanied by important discussions. This type of research is not always accepted and sometimes it is hard to justify its purpose. The main arguments against the studies include ambiguous definitions, the ostensible problems, and their normativity.

Problems with defining meta-subject research do not only relate to the multitude of definitions and the lack of consensus on the terminology and concepts used, although these issues are also relevant. Definitions used not always based on existing achievements but generated based on the author's intuitions are of much bigger concern. It happens that research in pedagogy does not always take into account the previous research in philosophy. It is not only about the achieved cognitive results, but also about the already indicated issues and functioning discussions. Knowledge of this type protects against both the sterility of conducted research (the so-called open-door balancing) and cognitive naivety (Bronk, 2005).

The allegation of meta-theoretical problems being cognitively ostensible is equally important. Meta-sciences are accused of inhibiting cognitive progress by replacing real research questions with methodological and theoretical selfreflections. This allegation is particularly clearly formulated in the field of applied sciences, including pedagogy. Theoretical and metatheoretical reflections are considered to be cognitively and practically pale, and sharing them is a waste of time and energy of researchers (Jakiel, 2015). 
The last group of accusations against metasciences relates to their normative nature. The sciences not only describe and explain science but formulate assessments, norms and postulates. Ultimately, they determine the correctness or incorrectness of science, and set its standards (Jakiel, 2015).

The normative and postulated nature of meta-subject sciences conflicts with the naturalistic critique of the normativity of science. It is culturally (mainly postmodern) conditioned by aversion to evaluation. What is more, it introduces the problem of the justification of science-bound norms and postulates. Solutions adopted in this area are not treated as universal, but as one of many possible forms of doing science (Hejnicka-Bezwińska, 2008).

\section{Conclusion}

Meta-subject research is an important element of modern science. It is an irreplaceable aspect of description, explanation and assessment of the correctness of research and scientific knowledge. Despite the fact that it does not directly solve any subject-related problems, it conditions the reliability and development of science.

In pedagogy, meta-subject research is of utmost importance. Although this type of reflection is sometimes marginalized, it is nevertheless necessary to determine the scientific status of pedagogy, and thus to support its aspiration for autonomy. This is all the more important because pedagogy, like other humanities, faces recurring criticism about the specificity of its scientific character. In this context, meta-subject reflection seems to be irreplaceable, because thanks to analyses conducted at the meta level, one can answer questions related to the characteristics of the subject of research, goals, language, research methods or the structure of pedagogy. In it, the theoretical foundations of pedagogy are also determined.

It is impossible to ignore the importance of meta-subject research in pedagogy also because of the rich traditions. Although meta-scientific achievements of Polish science are substantial, they remain largely unknown. This applies to both philosophy and pedagogy. It shows both a lack of knowledge in this area and the infatuation of native scientists with foreign scientific discourses, which often causes ignorance towards our own achievements. ${ }^{2}$

This text merely introduces the issue of metapedagogy. The presented analyses are necessarily fragmentary and incomplete. Undoubtedly, they require further research and additions. It seems that significant methodological and meta-theoretical

2 "As for tradition, (together with the outbreak of independence) mathematical logic exploded in Poland before the war. With it somehow - or within the logic of the broad sense - semiotic-methodological and epistemological issues developed. An [...] opinion was created (H. Scholz) about Poland as a country of 'beautiful and honorable traditions' in the field of logic. It would be something extremely irrational not to prolong this tradition.” (Bronk \& Majdański, 2010, p. 18). 
achievements earned at many Polish universities are worth recalling. The author hopes that he managed to encourage readers to study these achievements.

\section{References}

Ajdukiewicz, K. (2006). Metodologia i metanauka. In K. Ajdukiewicz, Język i poznanie, vol. 2 (pp. 117-126). Warszawa: Wydawnictwo Naukowe PWN.

Bronk, A. (2003). Czy pedagogika jest nauką autonomiczną? In M. Nowak. T. Ożóg, A. Rynio (Eds.), W trosce o integralne wychowanie (pp. 47-76). Lublin: Wydawnictwo KUL.

Bronk, A., \& Majdański, S. (2010). Metodologia nauk: jej zadania i potrzeby wczoraj i dziś. In M. Walczak (Ed.). Metodologia: tradycja i perspektywy (pp. 9-20). Lublin: Wydawnictwo KUL.

Bronk, A. (2005). Pedagogika i filozofia: uwagi metafilozoficzne. In P. Dehnel, P. Gutowski (Eds.), Filozofia a pedagogika. Szkice i studia (pp. 9-27). Wrocław: Wydawnictwo Naukowe Dolnośląskiej Szkoły Wyższej Edukacji TWP we Wrocławiu.

Danysz, A. (1918). O kształceniu. Lwów: Wydawnictwo Macierzy Polskiej.

Gutowski, P., \& Szubka, T. (1997). Metafilozofia. In J. Herbut (Ed.). Leksykon filozofii klasycznej (pp. 352-354). Lublin: Towarzystwo Naukowe KUL.

Hejnicka-Bezwińska, T. (2008). Pedagogika ogólna. Warszawa: Wydawnictwa Akademickie i Profesjonalne.

Horowski, J. (2015). Wychowanie moralne według pedagogiki neotomistycznej. Toruń: Wydawnictwo Naukowe Uniwersytetu Mikołaja Kopernika.

Jakiel, R. (2015). Kilka uwag o naukowej refleksji wyższego rzędu. Tekstoteka Filozoficzna, 4(3), 6-13.

Jusiak, J. (2006). Metafilozofia. In A. Maryniarczyk (Ed.), Powszechna Encyklopedia Filozofii, vol. 7 (pp. 83-90). Lublin: Polskie Towarzystwo Tomasza z Akwinu.

Kamiński, S. (1992). Nauka i metoda. Pojęcie nauki i klasyfikacja nauk. Lublin: Towarzystwo Naukowe KUL.

Kot, S. (1996). Historia wychowania, vol. 1. Warszawa: Wydawnictwo Akademickie Żak.

Kostkiewicz, J. (2017). Wprowadzenie. Zarys pedagogiki ogólnej Andrzeja Niesiołowskiego - o koncepcji i jej rękopisie powstałym w niemieckich oflagach. In A. Niesiołowski, Zarys pedagogiki ogólnej: rękopisy z oflagu (pp. 13-71). Kraków: Wydawnictwo Uniwersytetu Jagiellońskiego.

Kwieciński, Z. (1993). Mimikra czy sternik? Dramat pedagogiki w sytuacji przesilenia formacyjnego. In Z. Kwieciński \& L. Witkowski (Eds.), Spory o edukację. Dylematy i kontrowersje we współczesnych pedagogiach (pp. 7-24). Warszawa: Instytut Badań Edukacyjnych.

Magier, P. (2010). Koncepcja pedagogiki klasycznej. Roczniki Pedagogiczne, 2(38), 41-52. 
Magier, P. (2019). Metateoria pedagogiki chrześcijańskiej. Lublin: Towarzystwo Naukowe KUL.

Materne, J. (2001). Pedagogika ogólna a ogólna nauka o wychowaniu. In A. Bogaj (Ed.), Rozwój pedagogiki ogólnej. Inspiracje i ograniczenia kulturowe i poznawcze (pp. 124-135.). Warszawa-Kielce: Wydawnictwo Instytutu Badań Edukacyjnych w Warszawie.

Milerski, B. (2005). Pedagogika protestancka. In T. Pilch (Ed.), Encyklopedia pedagogiczna XXI wieku, vol. 4 (pp. 206-220). Warszawa: Wydawnictwo Akademickie Żak.

Nowak, M. (2008). Teorie i koncepcje wychowania. Warszawa: Wydawnictwa Akademickie i Profesjonalne.

Nowak, M. (1999). Podstawy pedagogiki otwartej. Lublin: Redakcja Wydawnictw KUL.

Rembierz, M. (2011). Metamorfozy metafilozofii. In M. Woźniczka (Ed.), Metafilozofia: nieporozumienie czy szansa filozofii? (pp. 129-174). Kraków: Wydawnictwo „Scriptum”.

Stępkowski, D. (2008). Miedzy pedagogiką a filozofią Herbarta. Roczniki Nauk Społecznych. Zeszyt 2 - Pedagogika, 36(2), 75-97.

Śliwerski, B. (2007). Istota i przedmiot badań teorii wychowania. In Z. Kwieciński \& B. Śliwerski (Eds.), Pedagogika. Podręcznik akademicki, vol. 2 (pp. 14-27). Warszawa: Wydawnictwo Naukowe PWN.

Śliwerski, B. (2019). Pedagogika jako nauka. In Z. Kwieciński \& B. Śliwerski (Eds.), Pedagogika. Podręcznik akademicki (pp. 13-39). Warszawa: Wydawnictwo Naukowe PWN.

Woleński, J. (2011). Metafilozofia a filozofia. In M. Woźniczka (Ed.), Metafilozofia: nieporozumienie czy szansa filozofii? (pp. 15-30). Kraków: Wydawnictwo „Scriptum”.

Zięba, W. (2014). Spory wokół metafilozofii. Sofia, 14(2), 211-222.

\section{BADANIA METAPRZEDMIOTOWE W POLSKIEJ PEDAGOGICE. WPROWADZENIE W PROBLEMATYKĘ}

Streszczenie: Artykuł ma charakter wprowadzający, elementarny. Jego celem jest problemowa analiza wybranych aspektów dorobku pedagogiki w zakresie badań metaprzedmiotowych. Poruszone w nim zostały zagadnienia dotyczące genezy badań metaprzedmiotowych, ich definiowania, typologizacji, funkcji oraz krytyki.

Słowa kluczowe: badania metaprzedmiotowe, pedagogika, geneza badań metaprzedmiotowych, typy badań metaprzedmiotowych, funkcje badań metaprzedmiotowych. 